\title{
Spectrum of carcinoembryonic antigen immunoreactivity from isolated ductal hyperplasias to atypical hyperplasias associated with infiltrating ductal breast cancer
}

\author{
F C Schmitt, L Andrade
}

\begin{abstract}
Aims-To study the immunohistochemical expression of carcinoembryonic antigen (CEA) in ductal hyperplasia of the breast and to investigate its putative relation with atypia and co-existing infiltrating ductal carcinoma.

Methods-Paraffin wax embedded tissue from 37 cases of isolated ductal hyperplasia (five with atypia and 32 without atypia) and 25 cases of ductal hyperplasia associated infiltrating ductal carcinoma (IDC) (seven with atypia and 18 without atypia) was stained with a monoclonal anti-CEA antibody using a standard avidin biotin immunoperoxidase method. Results-CEA immunoreactivity was observed in eight $(12 \cdot 8 \%)$ ductal hyperplasia cases. The percentage of CEA positivity in ductal hyperplasia cases with atypia (33.3\%) was substantially higher than that observed in cases of ductal hyperplasia without atypia $(8 \cdot 0 \%)$. Six cases of ductal hyperplasia associated IDC reacted with CEA; in these six cases the neoplastic cells of the co-existing carcinoma were also CEA positive. The percentage of CEA immunoreactivity in ductal hyperplasia associated IDC was higher than that observed in isolated ductal hyperplasia (24.0 $v 5.4 \%)$. The percentage of CEA immunoreactivity in atypical ductal hyperplasia associated IDC was similar to that observed in IDC alone $(42.9 v 40.0 \%)$.
\end{abstract}

Conclusions-The presence of CEA immunoreactivity has been confirmed in benign proliferative breast lesions. The prevalence of such immunoreactivity increases from $3 \cdot 1 \%$ in isolated, nonatypical ductal hyperplasia to $42.9 \%$ in atypical ductal hyperplasia associated IDC. This finding and the similarity of the frequency of CEA positivity in atypical ductal hyperplasia associated IDC and in IDC alone suggests that there is a pathogenetic link between ductal hyperplasia and some types of breast cancer. (F Clin Pathol 1995;48:53-56)

Keywords: Ductal hyperplasia, carcinoembryonic antigen, breast cancer.

Women with a history of benign breast disease have an increased risk of subsequent breast cancer. ${ }^{1}$ This increased risk is more evident among women with a proliferative epithelial component in their disease. ${ }^{2}$ At present, the relation between benign and malignant breast disease is unclear. Benign lesions may either be an early stage in the progression to malignant disease or completely independent. ${ }^{3}$

Ductal hyperplasia is a form of benign breast disease characterised by proliferation of the epithelium into the lumen. ${ }^{4}$ The phenotypic and genotypic patterns of these lesions have not been extensively studied. Recently, similarities were found between ductal hyperplasia and breast carcinoma cells with regard to DNA content and expression of some immunohistochemical markers. ${ }^{5-8}$

Carcinoembryonic antigen (CEA) is a member of the immunoglobulin supergene family and probably acts as an accessory molecule to cell adhesion, and is often used as a marker of malignancy..$^{9-11}$ The association between CEA immunoreactivity and breast cancer is well established despite the quite different figures in the literature, ranging from a minimum of $42.8 \%$ to a maximum of $90.0 \%$, reported, respectively, by $\mathrm{Nap}$ et $a l^{12}$ and Alexiev et al. ${ }^{13}$

Data on the putative association between CEA immunoreactivity and benign breast lesions are scarce and controversial. Most authors did not find any immunoreactivity at all, ${ }^{12-14}$ whereas others found immunoreactivity ranging from a minimum of $5 \cdot 2 \%{ }^{15}$ to a maximum of $42 \cdot 1 \% .^{16}$ This controversy partly reflects the well known variations in the specificity and sensitivity of anti-CEA sera, ${ }^{12} 1718$ and may also depend on the types of lesions classified as benign.

In a previous study we found CEA immunoreactivity in one of 18 cases of ductal hyperplasia. ${ }^{19}$ We aimed to expand the aforementioned series in an attempt to determine whether this immunoreactivity is related to the presence of atypia and co-existing invasive ductal carcinoma.

\section{Methods}

Breast tissue was obtained from 62 patients following biopsy, plastic surgery or mastectomy. In all cases histological slides from paraffin wax embedded material were critically reviewed and classified according to the criteria of Page and Anderson ${ }^{4}$ : ductal hyperplasia without atypia was defined as swirling patterns of cells with intercellular borders, usually ill defined, with an irregular nuclear shape, chromasia and position, and irregular, often ragged, serpiginous slit-like secondary spaces. Atypical ductal hyperplasia was defined as partial involvement of the basement 
Table 1 CEA immunoreactivity in isolated ductal hyperplasia $(D H)$ with and without atypia, and in ductal hyperplasia associated IDC with and without atypia

\begin{tabular}{|c|c|c|c|}
\hline & \multicolumn{3}{|l|}{$C E A$} \\
\hline & $\begin{array}{l}\text { Positive } \\
n(\%)\end{array}$ & $\begin{array}{l}\text { Negative } \\
n(\%)\end{array}$ & $\begin{array}{l}\text { Total } \\
n\end{array}$ \\
\hline $\begin{array}{l}\text { Isolated DH } \\
\text { with atypia } \\
\text { without atypia } \\
\text { DH associated IDC } \\
\text { with atypia } \\
\text { without atypia }\end{array}$ & $\begin{array}{l}2(5 \cdot 4) \\
1(20 \cdot 0) \\
1(3 \cdot 1) \\
6(24 \cdot 0) \\
3(42 \cdot 9) \\
3(16 \cdot 7)\end{array}$ & $\begin{array}{r}35(94 \cdot 6) \\
4(80 \cdot 0) \\
31(96 \cdot 9) \\
19(76 \cdot 0) \\
4(57 \cdot 1) \\
15(83 \cdot 3)\end{array}$ & $\begin{array}{r}37 \\
5 \\
32 \\
25 \\
7 \\
18\end{array}$ \\
\hline
\end{tabular}

membrane bound space by evenly spaced uniform cells with uniformly oval to rounded nuclear features and distinct intercellular borders. Non-atypical cells were frequently columnar, polarised cells of the type seen in the ducts immediately above the basement membrane. Following these criteria, the 37 cases of isolated ductal hyperplasia were divided into those with $(n=5)$ and without atypia $(n=32)$. The 25 cases of ductal hyperplasia associated infiltrating ductal carcinoma (IDC) were also divided into those with $(\mathrm{n}=$ 7 ) and without atypia $(n=18)$. In all cases of isolated ductal hyperplasia the patients were followed for a minimum of five years with no signs of breast cancer.

Formalin fixed, paraffin wax embedded tissue sections, $4 \mu \mathrm{m}$ thick, were stained with the CEA monoclonal antibody (Boeringher, Indianapolis, Indiana, USA) the epitope reactivity of which has not been characterised, ${ }^{17}$ using an avidin biotin complex immunoperoxidase method. All sections were predigested with $0 \cdot 1 \%$ trypsin (Sigma, St Louis, Missouri, USA) for 20 minutes at room temperature to reveal the immunological binding sites before the immunoperoxidase reactions. Slides with primary antibody were incubated for two hours at room temperature. A standard avidin biotin complex method (Vector Labs, Burlingame, California, USA) was used with 3,3'-diaminobenzidine (Sigma) as the chro-

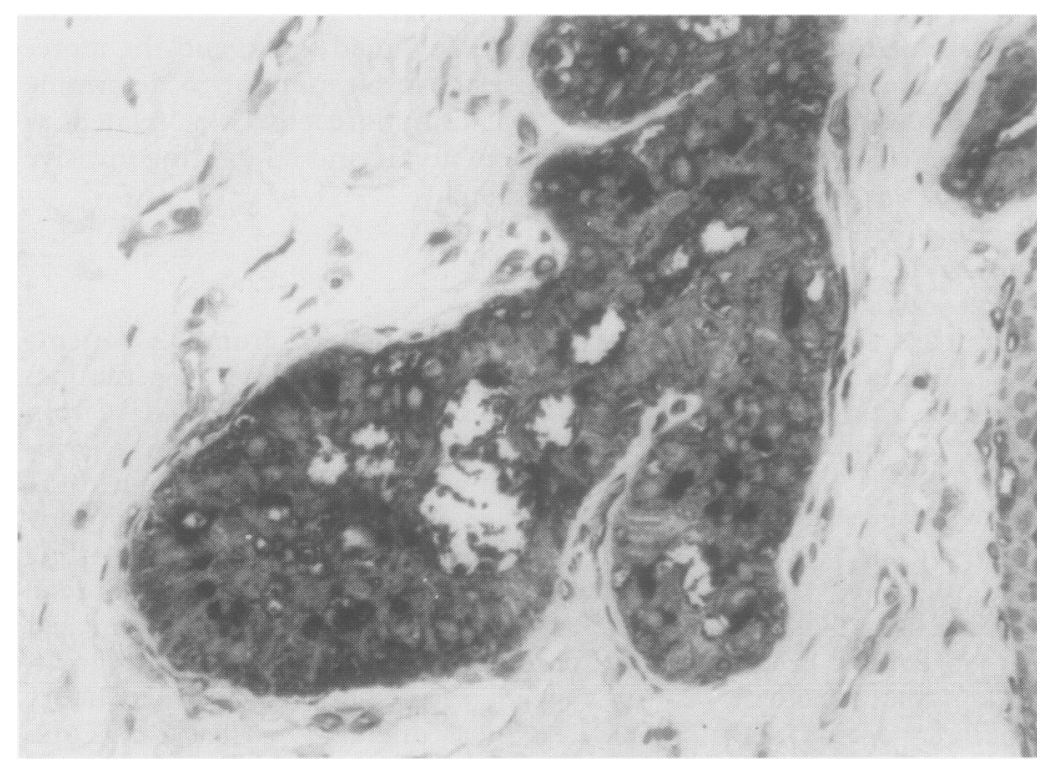

Figure 1 CEA immunostaining in a case of isolated ductal hyperplasia. mogen and haematoxylin as the counterstain. Sections of colonic adenocarcinoma were used as positive controls. Specific antisera were replaced by normal sera and used as negative controls.

CEA positivity was evaluated immunohistochemically by estimating the percentage of immunostained cells (at least 100 cells were counted in each case) and by assessing the intensity-graded as follows: weak $(+)$; strong $(++)$; and very strong $(+++)$-and the location of staining within each cell. Cases with no or weak staining in less than $5 \%$ of cells were regarded as negative. Cases in which only apical or luminal border staining was observed were also regarded as negative because such immunoreactivity has been found in normal breast tissue and may represent cross-reactivity with proteins from the glycocalix. ${ }^{14}$ Cases were regarded as "positive" when more than $1 \%$ of the cells displayed either strong or very strong cytoplasmic immunoreactivity.

Borderline cases - that is, cases in which a high percentage of cells displayed weak immunostaining and cases in which a small percentage of cells displayed strong or very strong immunoreactivity, were not found in our series.

Sections of colonic adenocarcinoma were always positive for CEA, while omission of primary antisera resulted in the complete loss of immunoreactivity.

\section{Results}

The results are summarised in table 1 . The mean age of those patients with isolated ductal hyperplasia was 40 years (range 17-60 years) and of those with ductal hyperplasia associated IDC was 54 years (range 31-75 years). The percentage of atypia in cases of isolated ductal hyperplasia was similar to that in cases of ductal hyperplasia associated IDC (21.6 v $28.0 \%$ )

CEA immunoreactivity was observed in eight $(12 \cdot 8 \%)$ cases of ductal hyperplasia. The hyperplastic cells showed strong cytoplasmatic positivity (fig 1). Myoepithelial cells were consistently CEA negative. The percentage of CEA positivity in cases of ductal hyperplasia with atypia (33.3\%) was significantly higher $(p<0.05)$ than that in those without atypia $(8 \cdot 0 \%)$.

Six ductal hyperplasia associated IDC cases were positive for CEA (table 1). In these six cases the neoplastic cells of the co-existing carcinoma were also CEA positive. CEA immunoreactivity was observed in 10 of the $25(40.0 \%)$ IDC cases (fig 2), including four cases in which adjacent ductal hyperplasia cells were negative. CEA expression was not observed in ductal hyperplasia associated non-immunoreactive IDC. Only two $(5 \cdot 4 \%)$ cases of isolated ductal hyperplasia exhibited CEA positivity. The percentage of CEA immunoreactivity in ductal hyperplasia associated IDC was higher, although not significantly $(\mathrm{p}<0.20)$, than that in isolated ductal hyperplasia $(24.0 v 5.4 \%)$. 


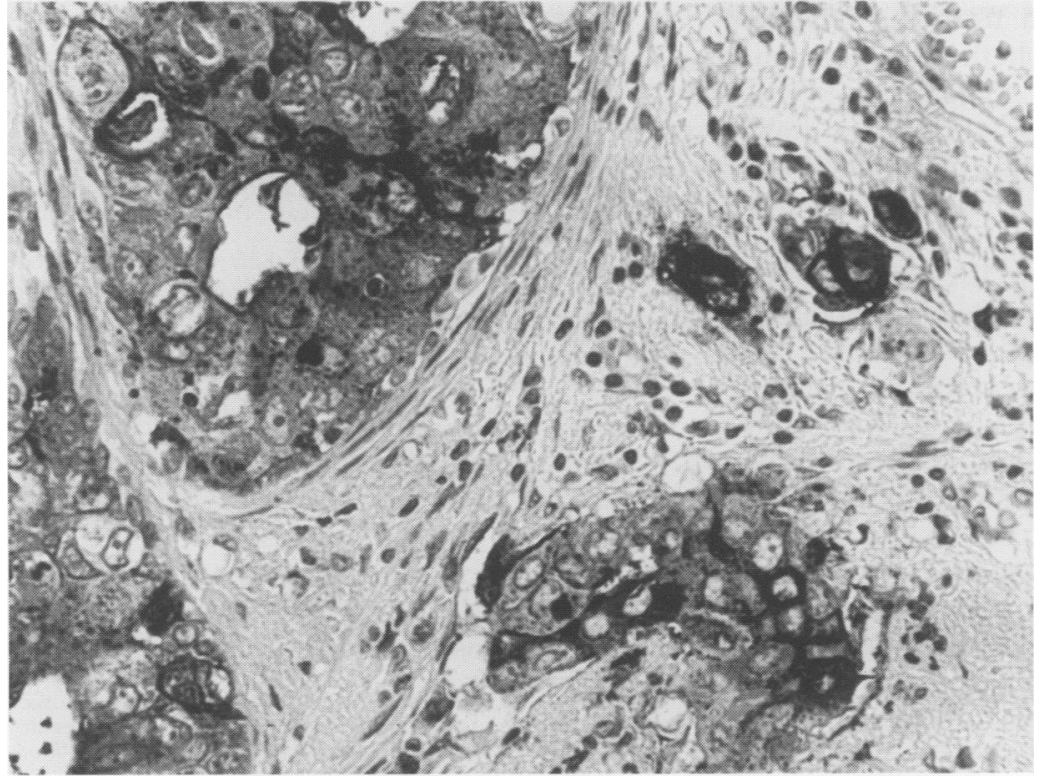

Figure 2 CEA immunostaining in a case of infiltrating ductal carcinoma. Note the immunoreactivity within the intraductal component of the tumour.

Polymorphonuclear leucocytes in breast epithelial tissue sections were always negative for CEA, excluding a putative cross-reaction with non-specific cross-reacting antigen.

\section{Discussion}

The major concern when using CEA as a putative marker of malignant transformation is to choose an antibody with appropriate specificity and sensitivity, ${ }^{17}$ as the different preparations of anti-CEA sera produce varying results. ${ }^{12}$ The large CEA molecule may also cross-react with several normal antigens present in some tissues. ${ }^{20}$ Despite these drawbacks, monoclonal and well absorbed polyclonal anti-CEA sera have unequivocally reacted with non-malignant epithelia. ${ }^{19} 2122$ In these cases CEA expression was related to disorders of cell growth and differentiation. Hasleton $e a^{23}$ reported expression of CEA in rectal polyps which progressed to cancer. Greaves et $a l^{21}$ observed CEA positivity in adenomas and metaplastic polyps of the large bowel, while Maxwell et $a l^{21}$ observed CEA positive staining in the dysplastic epithelium of the biliary tract.

The present study confirms our previous finding of CEA positivity in a single proliferative benign breast lesion. ${ }^{19}$ It shows, moreover, that the frequency of immunoreactivity differs between isolated ductal hyperplasia and ductal hyperplasia associated IDC. The frequency of CEA expression in benign breast lesions also varies (table 2). Several authors did not observe positive staining for CEA in these lesions, ${ }^{12-14}$ whereas others reported CEA positivity in a large number of nonmalignant breast lesions. ${ }^{12} 15161824$ These discrepant results are difficult to evaluate from a critical point of view because the antibodies as well as the morphological criteria and the immunohistochemical methods vary from series to series (table 2 ).

In material obtained using fine needle aspiration Kandaraki et al ${ }^{16}$ reported a high frequency of CEA immunoreactivity in benign breast lesions $(42 \cdot 1 \%)$, but these authors did not classify the lesions studied in their series. Our data, showing CEA immunoreactivity in $5.4 \%$ cases of isolated ductal hyperplasia, support the hypothesis that CEA positivity is not restricted to malignant cells in the breast. As CEA expression is not restricted to malignant cells in other tissues, ${ }^{21}{ }^{22}$ it is not surprising that some cases of benign breast disease are CEA positive.

Papotti et $a l^{24}$ and Kuhajda et $a l^{15}$ observed CEA positive staining in papillomas (table 2). Furthermore, Papotti et al ${ }^{24}$ suggested that the progression from multiple intraductal papillomas to breast cancer was related to CEA expression. Lee et $a l^{18}$ observed CEA positivity in atypical ductal hyperplasia associated IDC without mentioning the frequency of this observation. In the present study we observed three distinct levels of CEA immunoreactivity: $3 \cdot 1 \%$ in isolated, non-atypical ductal hyperplasia; 16.7 and $20.0 \%$, respectively, in non-atypical ductal hyperplasia associated IDC and isolated atypical ductal hyperplasia; and $42.9 \%$ in atypical ductal hyperplasia associated IDC. The important

Table 2 Summary of the prevalence of CEA immunoreactivity in benign breast lesions

\begin{tabular}{|c|c|c|c|c|c|c|c|c|c|}
\hline Reference & $\begin{array}{l}\text { Source } \\
\text { of } C E A\end{array}$ & $\begin{array}{l}\text { Staining } \\
\text { method }\end{array}$ & $\begin{array}{l}\text { Papilloma } \\
(\%)\end{array}$ & $\begin{array}{l}\text { Fibro- } \\
\text { adenoma } \\
(\%)\end{array}$ & $\begin{array}{l}\text { Isolated } \\
\text { DH } \\
\text { without } \\
\text { atypia } \\
(\%)\end{array}$ & $\begin{array}{l}\text { DH } \\
\text { associated } \\
\text { IDC } \\
\text { without } \\
\text { atypia } \\
(\%)\end{array}$ & $\begin{array}{l}\text { Isolated } \\
\text { DH } \\
\text { with } \\
\text { atypia } \\
(\%)\end{array}$ & $\begin{array}{l}\text { DH } \\
\text { associated } \\
\text { IDC } \\
\text { with } \\
\text { atypia } \\
(\%)\end{array}$ & $\begin{array}{l}\text { Total } \\
\text { benign } \\
\text { lesions } \\
(\%)\end{array}$ \\
\hline Nap, et al ${ }^{12}$ & $\begin{array}{l}\text { Hoffman-La Roche } \\
\text { (Basel, Switzerland) }\end{array}$ & PAP & - & 0 & 0 & 0 & - & - & 0 \\
\hline Alexiev, et al ${ }^{13}$ & $\begin{array}{l}\text { Biogenex } \\
\text { (Dublin, Ireland) } \\
\text { (Clone SP651) }\end{array}$ & Streptavidin & - & 0 & 0 & - & - & - & 0 \\
\hline De Potter, et al ${ }^{14}$ & $\begin{array}{l}\text { Amersham } \\
\text { (Amersham, UK) } \\
\text { (ac RNN8) }\end{array}$ & PAP & - & - & 0 & 0 & 0 & 0 & 0 \\
\hline Kuhajda, et al ${ }^{15}$ & $\begin{array}{l}\text { Dako } \\
\text { (Santa Barbara, USA) }\end{array}$ & PAP & $25 \cdot 0$ & - & - & - & - & 0 & $5 \cdot 2$ \\
\hline Kandaraki, et al ${ }^{16}$ & Not given & Not given & - & - & - & - & - & - & $42 \cdot 1$ \\
\hline Lee, et al ${ }^{18}$ & Dako & $\mathrm{ABC}$ & - & - & - & - & - & $\begin{array}{l}\text { Some } \\
\text { cases }\end{array}$ & - \\
\hline Schmitt, et al ${ }^{19}$ & $\begin{array}{l}\text { Boehringer } \\
\text { (Indianapolis, USA) }\end{array}$ & $\mathrm{ABC}$ & - & - & 0 & - & $5 \cdot 5$ & - & $5 \cdot 5$ \\
\hline Papotti, et al ${ }^{24}$ & $\begin{array}{l}\text { Hybritech } \\
\text { (La Jolla, USA) }\end{array}$ & Not given & $\begin{array}{l}\text { Some } \\
\text { cases }\end{array}$ & - & - & - & - & - & - \\
\hline Present study & Boehringer & $\mathrm{ABC}$ & - & - & $3 \cdot 1$ & $16 \cdot 7$ & $20 \cdot 0$ & $42 \cdot 9$ & $12 \cdot 9$ \\
\hline
\end{tabular}

$\mathrm{DH}=$ ductal hyperplasia; IDC = infiltrating ductal carcinoma; $\mathrm{PAP}=$ peroxidase-antiperoxidase method; $\mathrm{ABC}=$ avidin biotin peroxidase complex. 
question to be answered from the oncobiological point of view is whether the abnormal expression of CEA in hyperplastic breast lesions is related to the progression to malignancy. In the colorectum the adenomacarcinoma sequence is strongly supported by epidemiological, pathological, and genetic data. ${ }^{25}$ In these cases the CEA content of the adenomas increased gradually with increasing dysplasia. ${ }^{22}$ It is tempting to hypothesise that the ductal hyperplasia-carcinoma spectrum in the breast could be analogous. There is epidemiological, cytometric, and immunohistochemical evidence linking atypical proliferative epithelial breast lesions with breast cancer. ${ }^{256}$ Our finding of a similar prevalence of CEA expression in atypical ductal hyperplasia associated IDC $(42.9 \%)$ and in IDC $(40.0 \%)$ is suggestive of a pathogenetic link between ductal hyperplasia and some types of breast cancer.

We did not study a sufficient number of intraductal carcinoma cases to draw definitive conclusions about the biological role of this lesion in the progression to invasive cancer. Other series, however, have demonstrated a similar incidence of CEA immunoreactivity in intraductal and invasive carcinomas. ${ }^{14} 15$ In some of our cases we detected CEA positivity in intraductal carcinomas close to infiltrative areas (data not shown), which is suggestive of a pathogenetic link between these types of carcinoma. On the other hand, we observed four IDC cases which expressed CEA immunoreactivity without CEA positivity in the neighbouring ductal hyperplasia (including one case with atypia). Whether or not this finding represents an alternative route for breast carcinogenesis, as suggested by some authors, ${ }^{326}{ }^{27}$ has yet to be clarified.

Despite having demonstrated that the CEA expression is more frequently seen in atypical ductal hyperplasia associated with invasive cancer, we do not know if CEA expression by hyperplastic cells represents a new antigenic determinant associated with malignant transformation, as CEA messenger RNA (mRNA) has been detected in apparently normal mucosas. $^{28}$ To the best of our knowledge, analysis of CEA mRNA using northern blotting or in situ hybridisation of normal or hyperplastic breast epithelia has not been performed to date.

Bearing these observations in mind, prospective studies, including follow up and molecular biology studies of isolated ductal hyperplasia, mainly in CEA positive cases, are required to assess whether such immunoreactivity is indicative of an increased risk for malignant transformation.

We thank Professor M Sobrinho-Simões for his helpful advice in the revision and preparation of the manuscript.

Supported, in part, by research grant from the Conselho Nacional de Desenvolvimento Científico e TecnológicoCNPq (No 800686/91).

1 Kelsey JL, Gammon MD. Epidemiology of breast cancer. Epidemiol Rev 1990;12:228-40.

2 Dupont WD, Parl FF, Hartmann WH, Brinton LA Winfield AC, Worrell JA, et al. Breast cancer risk associated with proliferative breast disease and atypical hyperplasia. Cancer 1993;71:1258-65.

3 Azzopardi JG (ed). The histogenesis of early carcinomas.
In: Problems in breast pathology. Philadelphia: WB Saunders, 1979:103-11.

4 Page DL, Anderson TJ, Rogers LW. Epithelial hyperplasia. In: Page DL, Anderson TJ, eds. Diagnostic Livingstone, 1987:120-56.

5 Crissman JD, Visscher DW, Kubus J. Image cytophotometric DNA analysis of atypical hyperplasias and intraductal carcinomas of the breast. Arch Pathol Lab Med 1990;114:1249-53.

6 Eriksson E, Schimmelpenning H, Silfversward C, Auer G. Immunoreactivity with monoclonal antibody A-80 and nuclear DNA content in benign and malignant human breast disease. Hum Pathol 1992;23:1366-72.

7 Raju U, Crissam JD, Zarbo RJ, Gottlieb C. Epitheliosis of the breast: an immunohistochemical characterization the breast: an immunohistochemical characterization and comparison to malignant intraductal prolifer

8 Gould VE, Koukoulis GK, Jansson DS, Nagle RB, Franke WW, Moll R. Coexpression patterns of vimetin and glial filament protein with cytokeratins in the normal, hyperplastic and neoplastic breast. Am f Pathol 1990;137: 1143-55.

9 Thompsom JA, Pande H, Paxton RJ, Shively L, Padma A, Simmer RL, et al. Molecular cloning of a gene belonging to the carcinoembryonic antigen gene family and discussion of a domain model. Proc Natl Acad Sci USA 1987;84:2965-9.

10 Pignatelli M, Durbin H, Bodmer WF. Carcinoembryonic antigen functions as an accessory adhesion molecule mediating colon epithelial cell-collagen interactions. Proc Natl Acad Sci USA 1990;87:1541-5.

11 Gold P, Franchimont SO. Demonstration of tumor-specific antigens in human colonic carcinoma by immunological tolerance and absorption techniques. $\mathcal{F} \operatorname{Exp~Med}$ 1965;121:439-62.

12 Nap M, Keuning H, Burtin P, Oosterhuis JW, Fleuren G. CEA and NCA in benign and malignant breast tumors. Am $\mathcal{F}$ Clin Pathol 1984;82:526-34.

13 Alexiev BA, Valkov IN, Popov AA, Marinov VS Immunocytochemical detection of carcinoembryonic antigen in fine-needle aspirates from patients with diverse breast diseedle aspirates from patients with

14 De Potter CHR, Beghin C, Praet MM, Pauwels CF, Roels HJ. CEA and HMFG in hyperplastic and malignant lesions of the breast. Path Res Pract 1988;183:271-6.

15 Kuhajda FP, Offutt LE, Mendelsohn G. The distribution of carcinoembryonic antigen in breast carcinoma. Diagnostic and prognostic implications. Cancer 1983; 52:1257-64.

16 Kandaraki C, Veneti S, Athanassiades $P$, IoannidouMouzaka L, Papadimitriou G, Kyrkou K. An immunocytochemical study of actin and CEA in the diagnosis of suspicious breast aspirations. Acta Cytol 1993;37:599.

17 Esteban JM, Paxton R, Mehta P, Battifora H, Shively JE. Sensitivity and specificity of gold types 1 to 5 anti-carcinoembryonic antigen monoclonal antibodies: immunohistologic characterization in colorectal cancer and normal tissues. Hum Pathol 1993;24:322-8.

18 Lee AK, Rosen PP, DeLellis RA, Saigo PE, Gangi MD, Groshen S, et al. Tumor marker expression in breast carcinomas and relationship to prognosis. An immunohistochemical study. Am ₹ Clin Pathol 1985;84:687-96.

19 Schmitt FC, Andrade LM, Montenegro MR, DeLucca L, Bacchi CE. Antigenic profile of ductal hyperplasia of the breast. An immunohistochemical study and comparison to normal and malignant epithelium. Pathol Res Pract 1993;189:806

20 Neumaier M, Zimmermann W, Shively L, Hinoda Y, Riggs AD, Shively JE. Characterization of a cDNA clone for nonspecific cross-reacting antigen (NCA) and a comparison of NCA and carcinoembryonic antigen. $\mathcal{F} \mathrm{Biol}$ Chem 1988;263:3202-7.

21 Maxwell $P$, Davis RI, Sloan JM. Carcinoembryonic antigen (CEA) in benign and malignant epithelium of the gen (CEA) in benign and malignant epithelium of the galbladder, extrahepatic bile

22 Greaves P, Filipe MI, Abbas S, Ormerod MG. Sialomucins and carcinoembryonic antigen in the evolution of colorectal cancer. Histopathology 1984;8:825-34.

23 Hasleton PS, Shah S, Buckley CH. Ampullary carcinoma associated with multiple duodenal villous adenomas. $\mathrm{Am}$ f Gastroenterol 1980;73:418-22.

24 Papotti M, Gugliotta P, Ghiringhello B, Bussolati G Association of breast carcinoma and multiple intraductal papillomas. An histological and immunohistochemical investigation. Histopathology 1984;8:963-75.

25 Cannon-Albright LA, Skolnick MH, Bishop T, Lee RG, Burt RW. Common inheritance of susceptibility to colonic adenomatous polyps and associated colorectal cancers. N Engl $₹$ Med 1988;319:513.

26 Black MM, Kwan S. Precancerous mastopathy: structural and biological considerations. Pathol Res Pract 1980; 166:491-514.

27 Bocker W, Bier B, Freytag G, Brommelkamp B, Jarasch ED, Edel G, et al. An immunohistochemical study of the breast using antibodies to basal and luminal keratins,
alpha-smooth muscle actin, vimentin, collagen IV and alpha-smooth muscle actin, vimentin, collagen IV and laminin. Part II: epitheliosis and ductal carcinoma
situ. Virchows Arch A Pathol Anat 1992;421:323-30.

28 Cournoyer D, Beauchemin N, Boucher D, Benchimol S, Fuks A, Stanners CP. Transcription of genes of the carcinoembryonic antigen family in malignant and nonmalignant human tissues. Cancer Res 1988;48:3153-7. 